\title{
Synthesis of nanocrystalline alloys and intermetallics by mechanical alloying
}

\author{
S K PABI* and B S MUR'TY \\ Department of Metallurgical and Materials Engineering, Indian Institute of Technology, \\ Kharagpur 721302 , India
}

\begin{abstract}
Nanocrystalline $\mathrm{Al}_{3} \mathrm{Ni}, \mathrm{NiAl}$ and $\mathrm{Ni}_{3} \mathrm{Al}$ phases in $\mathrm{Ni}-\mathrm{Al}$ system and the $\alpha, \beta, \gamma$, $\varepsilon$ and deformation induced martensite in $\mathrm{Cu}-\mathrm{Zn}$ system have been synthesized by mechanical alloying $(\mathrm{MA})$ of elemental blends in a planetary mill. $\mathrm{Al}_{3} \mathrm{Ni}$ and $\mathrm{NiAl}$ were always ordered, while $\mathrm{Ni}_{3} \mathrm{Al}$ was disordered in the milled condition. MA results in large extension of the $\mathrm{NiAl}$ and $\mathrm{Ni}_{3} \mathrm{Al}$ phase fields, particularly towards $\mathrm{Al}$-rich compositions. $\mathrm{Al}_{3} \mathrm{Ni}$, a line compound under equilibrium conditions, could be synthesized at nonstoichiometric compositions as well by MA. The phases obtained after prolonged milling $(30 \mathrm{~h})$ appear to be insensitive to the starting material for any given composition $>25$ at. $\% \mathrm{Ni}$. The crystallite size was finest $(\sim 6 \mathrm{~nm})$ when $\mathrm{NiAl}$ and $\mathrm{Ni}_{3} \mathrm{Al}$ phases coexisted after prolonged milling. In contrast, in all $\mathrm{Cu}-\mathrm{Zn}$ blends containing 15 to 85 at. $\% \mathrm{Zn}$, the $\mathrm{Zn}$-rich phases were first to form, and the final crystallite sizes were coarser $(15-80 \mathrm{~nm})$. Two different modes of alloying have been identified. In case of $\mathrm{NiAl}$ and $\mathrm{Al}_{3} \mathrm{Ni}$, where the ball milled product is ordered, as well as, the heat of formation $\left(\Delta H_{\mathrm{f}}\right)$ is large $(>120 \mathrm{~kJ} / \mathrm{mol}$ ), a rapid discontinuous mode of alloying accompanied with an additive increase in crystallite size is detected. In all other cases, irrespective of the magnitude of $\Delta H_{\mathrm{f}}$, a gradual diffusive mode of intermixing during milling seems to be the underlying mechanism of alloying.
\end{abstract}

Keywords. Mechanical alloying; nanocrystals; synthesis; $\mathrm{Al}-\mathrm{Ni} ; \mathrm{Cu}-\mathrm{Zn}$.

\section{Introduction}

The nanostructured solids exhibit noble properties like high strength and toughness, exceptionally high diffusivity and sinterability, unusual formability in conventionally brittle materials at ambient temperatures (Gleiter 1992; Koch 1993; Das and Pabi 1996). These enhanced properties are generally attributed to their large grain boundary volume (Gleiter 1992). However, recent high resolution electron microscopic results (Neiman et al 1991) have suggested that the volume of the "grain boundary phase' may not be appreciable in these materials.

Mechanical alloying (MA) is a high energy ball milling technique, pioneered by Benjamin (1970) in the early seventies. It has now established itself as a viable solid state processing route for the synthesis of novel materials (Koch 1991; Murty 1993). MA is an economic route of producing large quantities of nanostructured materials with good control over multicomponent product composition and homogeneity.

Intermetallic compounds, such as, aluminides have attracted the attention of many investigators (Miracle 1993; Noebe et al 1993) due to their high specific strength and high temperature capabilities. The possibility of improving the room temperature ductility of these otherwise brittle compounds has made MA as a promising technique for the synthesis of high performance intermetallic compounds either

* Author for correspondence 
directly by MA (Atzmon 1988; Calka and Radlinski 1990; Ivanov et al 1990; Shingu 1992; Cardellini et al 1993, 1994; Itsukaichi et al 1993; Mukhopadhyay et al 1994; Murty et al 1996; Pabi and Murty 1996; Pabi et al 1996) or by thermal treatment of mechanically alloyed powders (Benn et al 1988; Radlinski and Calka 1991; Murty 1992). However, reports on the mechanism of alloying during ball milling are relatively very few (Atzmon 1988; Zbiral et al 1992). By in situ measurement of vial temperature during MA in a SPEX mill, Atzmon (1988) reported that NiAl forms in the equiatomic mixture of $\mathrm{Ni}$ and $\mathrm{Al}$ through an explosive exothermic reaction similar to the self-propagating high temperature synthesis reaction (Munir 1992). Zbiral et al (1992) suggested that alloying in general occurs by the diffusion of either one element or both the elements depending on the equilibrium solid solubility. In an A-B system with significant solubility of B in A and relatively insolubility of A in B, alloying occurs by diffusion of B into A. In cases where the mutual solid solubility is appreciable, alloying seems to take place by diffusion of both the elements into each other. It is, however, not clear under what conditions such a diffusion model is applicable to the formation of compounds by MA. The present paper reports a systematic study of the mechanism of mixing in two model systems, namely, $\mathrm{Ni}-\mathrm{Al}$ and $\mathrm{Cu}-\mathrm{Zn}$, that have widely different heats of formation $\left(\Delta H_{\mathrm{f}}\right)$. In $\mathrm{Ni}-\mathrm{Al}$ system, the intermetallic compounds like $\mathrm{NiAl}, \mathrm{Ni}_{3} \mathrm{Al}$ or $\mathrm{Al}_{3} \mathrm{Ni}$ have large $\Delta H_{\mathrm{f}}$ of $>120 \mathrm{~kJ} / \mathrm{mol}$ (Kubaschewski et al 1967a). Moreover, $\mathrm{NiAl}$ is known to remain ordered up to its melting point, while $\mathrm{Ni}_{3} \mathrm{Al}$ seems to have a relatively low ordering energy $(5 \mathrm{~kJ} / \mathrm{mol})$ and low disordering temperature $(638 \mathrm{~K})$ (Aoki et al 1994; Koch and Cho 1992). In contrast, the intermetallic phases in $\mathrm{Cu}-\mathrm{Zn}$ system are electron compounds with low $\Delta H_{\mathrm{f}}(\sim 8 \mathrm{~kJ} / \mathrm{mol})(\mathrm{Kubaschewski}$ et al 1967b).

\section{Experimental}

High purity $\mathrm{Ni}$ and $\mathrm{Al}(99.9 \%)$ powders were mixed in the proportions of $\mathrm{Al}_{100-x} \mathrm{Ni}_{x}(x=10,18,21,25,40,50,65,68,70,75$ and 90$)$ and were mechanically alloyed in a Fritsch Pulverisette- 5 planetary mill. A prealloyed powder of composition $\mathrm{Al}-50$ wt. $\% \mathrm{Ni}\left(\mathrm{Al}_{70} \mathrm{Ni}_{30}\right)$ containing $\mathrm{Al}_{3} \mathrm{Ni}, \mathrm{Al}_{3} \mathrm{Ni}_{2}$ and $\mathrm{NiAl}$ phases was also ball milled under identical conditions with and without the addition of $\mathrm{Al}$ or $\mathrm{Ni}$ to achieve compositions of $\mathrm{Al}_{100-x} \mathrm{Ni}_{x}(x=10,18,21,25,30,40,50,65,68,70,75$ and 90). The milling was carried out at $300 \mathrm{rpm}$ in WC container in toluene using $10 \mathrm{~mm}$ diameter WC balls with ball to powder weight ratio of 10:1. Similarly, elemental blends of $\mathrm{Cu}(99.9 \%)$ and $\mathrm{Zn}(99.5 \%)$ of compositions $\mathrm{Cu}_{100-x} \mathrm{Zn}_{x}(x=15$, $30,40,50,65$ and 85 ) were also mechanically alloyed. The effect of milling speed (200 vs 300 ), type of balls (steel vs WC) and milling atmosphere (dry vs wet) on the phase formation during MA were studied for the $\mathrm{Cu}-\mathrm{Zn}$ system. Dry milling was carried out in air, while wet milling was performed in toluene. The mechanically alloyed powders were characterized by a Philips PW $1840 \mathrm{X}$-ray diffractometer with $\mathrm{CuK}_{\alpha}$ radiation at regular intervals of milling. The crystallite size was calculated from X-ray diffraction (XRD) peak broadening, after separation of the contributions of strain and instrumental broadening by standard procedure (Guinier 1963). The crystallite size was confirmed by transmission electron microscopy (TEM) using Philips CM12 electron microscope. 


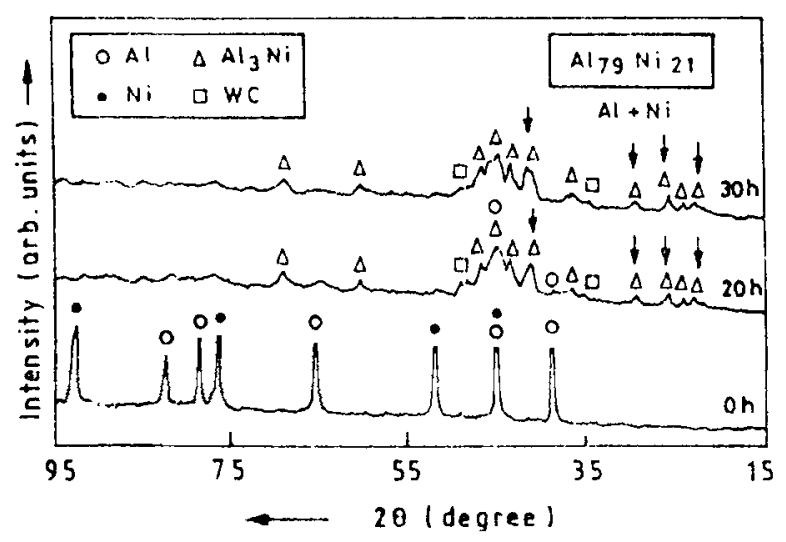

Figure 1. XRD patterns of $\mathrm{Al}_{79} \mathrm{Ni}_{21}$ blend as a function of milling time showing the evolution of $\mathrm{Al}_{3} \mathrm{Ni}$.

\section{Results}

\subsection{Synthesis of Ni aluminides by $M A$}

Nanocrystalline $\mathrm{Al}_{3} \mathrm{Ni}, \mathrm{NiAl}$ and $\mathrm{Ni}_{3} \mathrm{Al}$ have been synthesized by $\mathrm{MA}$ in the present study. MA of elemental blend of $\mathrm{Al}_{90} \mathrm{Ni}_{10}$ composition has shown pure metal mixture of $\mathrm{Al}$ and $\mathrm{Ni}$ without any aluminide formation even after $30 \mathrm{~h}$ of milling. In contrast, $\mathrm{Al}_{82} \mathrm{Ni}_{18}$ and $\mathrm{Al}_{79} \mathrm{Ni}_{21}$ have shown the formation of $\mathrm{Al}_{3} \mathrm{Ni}$. Figure 1 shows the evolution of $\mathrm{Al}_{3} \mathrm{Ni}$ in $\mathrm{Al}_{79} \mathrm{Ni}_{21}$ composition during $\mathrm{MA}$. The residual Al present after $20 \mathrm{~h}$ of milling in this case completely disappeared on further milling up to $30 \mathrm{~h}$. Some residual $\mathrm{Al}$, however, persisted in the case of $\mathrm{Al}_{82} \mathrm{Ni}_{18}$ even after $30 \mathrm{~h}$ of $\mathrm{MA}$. The superlattice reflections of $\mathrm{Al}_{3} \mathrm{Ni}$ indicated by arrow-heads in figure 1 confirm that the $\mathrm{Al}_{3} \mathrm{Ni}$ generated by MA remains ordered in the milled condition. The absence of shift in the XRD peaks of $\mathrm{Al}$ in these alloys suggests that ball milling is not effective in extending the solid solubility of $\mathrm{Ni}$ in $\mathrm{Al}$.

Contrary to the expectations, $\mathrm{MA}$ of $\mathrm{Al}$ and $\mathrm{Ni}$ in stoichiometric ratio of $\mathrm{Al}_{3} \mathrm{Ni}$, i.e. $\mathrm{Al}_{75} \mathrm{Ni}_{25}$ blend has shown that $\mathrm{Al}_{3} \mathrm{Ni}$ formed along with $\mathrm{NiAl}$ in the early stages $(12 \mathrm{~h})$ of milling disappears on further milling up to $20 \mathrm{~h}$, leaving behind $\mathrm{NiAl}$, as reported earlier (Murty et al 1996). Single phase NiAl was also found to be the end product of milling for $\mathrm{Al}_{60} \mathrm{Ni}_{40}$ and $\mathrm{Al}_{50} \mathrm{Ni}_{50}$ compositions. Figure 2 illustrates the evolution of $\mathrm{NiAl}$ in course of milling of $\mathrm{Al}_{50} \mathrm{Ni}_{50}$ elemental blend. Here the formation of $\mathrm{NiAl}$ can be noticed within $8 \mathrm{~h}$ of MA. Further milling, up to $16 \mathrm{~h}$, resulted in the disappearance of XRD peak for Al, while the Ni peaks persisted up to $20 \mathrm{~h}$. The NiAl produced in all the compositions was ordered, as manifested by the superlattice reflections (e.g. see arrow-head in figure 2). The nanocrystalline nature of the NiAl synthesized in the present study can be clearly seen from the TEM bright field image in figure 3 . Average size of the particles was about $10 \mathrm{~nm}$. The selected area electron diffraction pattern from these particles (inset of figure 3 ) confirms the absence of any amorphous phase.

MA of $\mathrm{Al}_{35} \mathrm{Ni}_{65}$ and $\mathrm{Al}_{32} \mathrm{Ni}_{68}$ has shown a two-phase mixture of ordered $\mathrm{NiAl}$ and disordered $\mathrm{Ni}_{3} \mathrm{Al}$. MA of Ni-rich compositions (70-90 at.\% $\mathrm{Ni}$ ) has yielded single phase disordered $\mathrm{Ni}_{3} \mathrm{Al}$. Formation of disordered $\mathrm{Ni}_{3} \mathrm{Al}$ during MA is clearly evident from figure 4 . No XRD peak shifts were observed for $\mathrm{Al}$, while $\mathrm{Ni}$ peaks shifted 


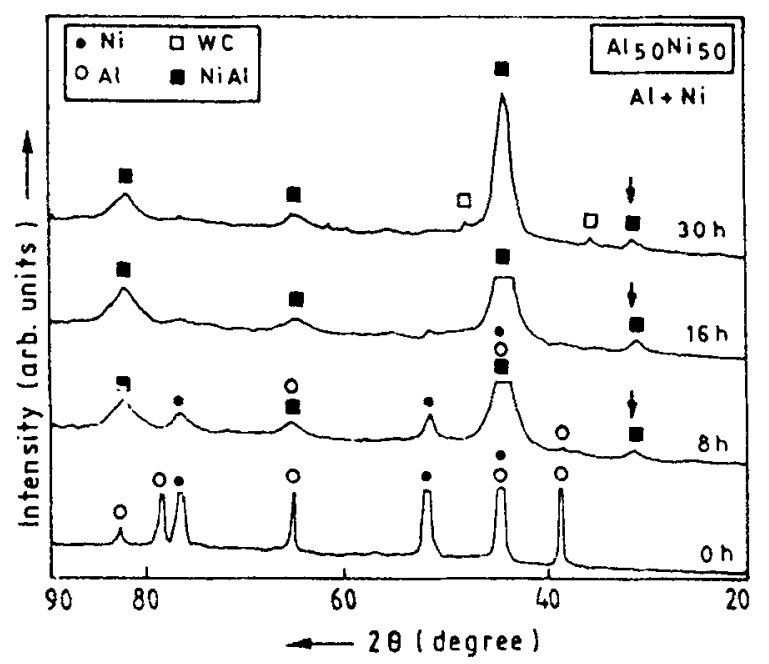

Figure 2. XRD patterns of $\mathrm{Ni}_{50} \mathrm{Al}_{50}$ blend at different milling times showing $\mathrm{NiAl}$ formation.

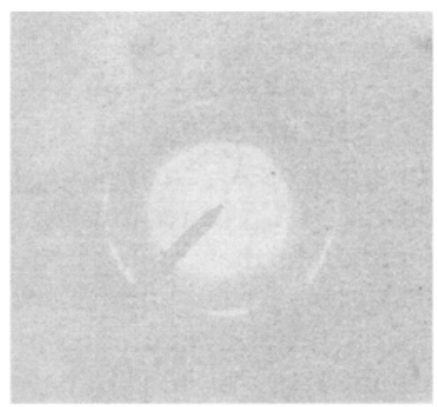

Figure 3. TEM bright field image of nanocrystalline NiAl. Inset shows the selected area diffraction pattern from $\mathrm{NiAl}$.

continuously towards the $\mathrm{Ni}_{3} \mathrm{Al}$ peak positions with increase in milling time. Within $20 \mathrm{~h}$ of milling, the peak positions matched closely with the fundamental lines of $\mathrm{Ni}_{3} \mathrm{Al}$ and no peak shifts were observed with further milling. As the peak positions of the phase formed matched perfectly with the fundamental reflections of $\mathrm{Ni}_{3} \mathrm{Al}$ in all the $\mathrm{Ni}$-rich compositions studied (i.e. 70,75 and 90 at. $\% \mathrm{Ni}$ ), the phase formed is referred to as disordered $\mathrm{Ni}_{3} \mathrm{Al}$ rather than solid solution of $\mathrm{Al}$ in $\mathrm{Ni}$, i.e. $\mathrm{Ni}(\mathrm{Al})$. 


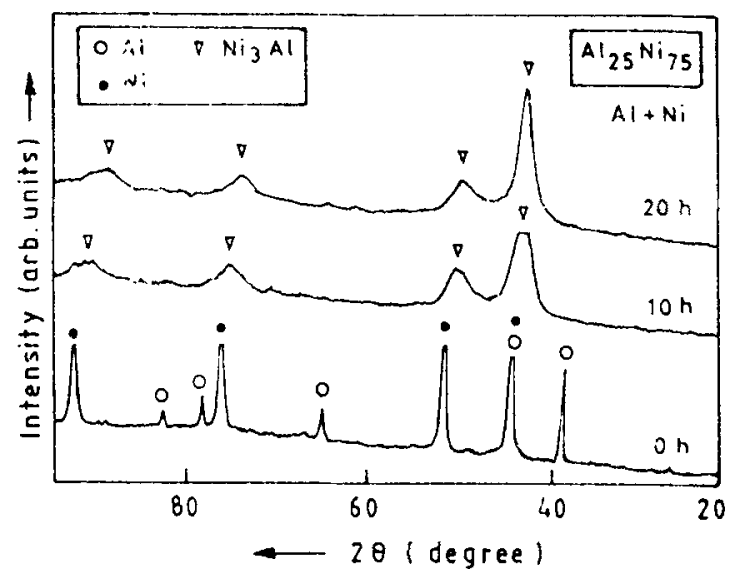

Figure 4. XRD patterns of $\mathrm{Al}_{25} \mathrm{Ni}_{75}$ at different milling intervals depicting the formation of disordered $\mathrm{Ni}_{3} \mathrm{Al}$.

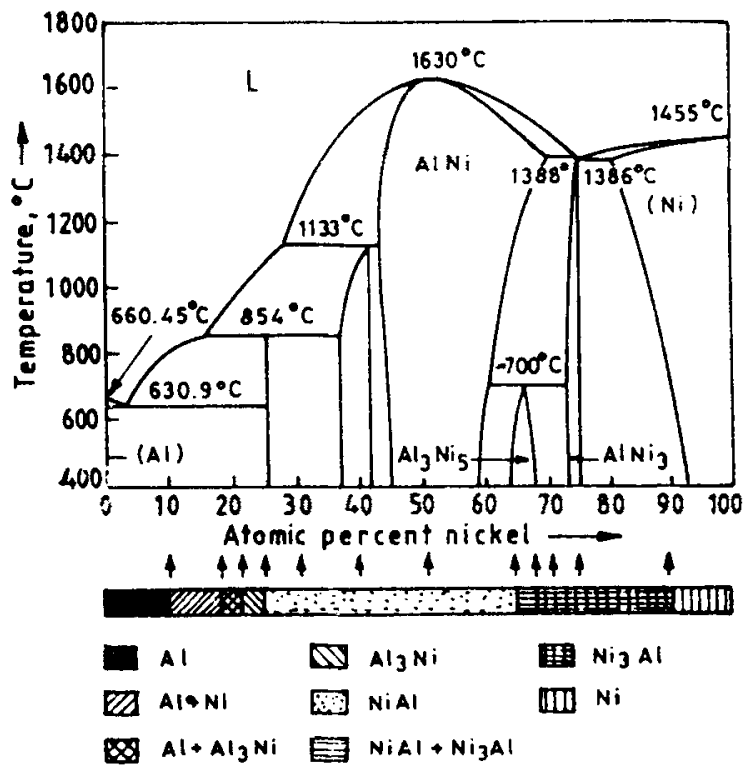

Figure 5. Ni-Al phase diagram showing the equilibrium phase fields of different aluminides. The bar below the phase diagram gives the large extension of phase fields of the aluminides obtained in $\mathrm{Ni}-\mathrm{Al}$ system after $30 \mathrm{~h}$ of $\mathrm{MA}$.

Figure 5 compares the phase field extensions obtained by MA for the aluminides with their equilibrium phase fields. Interestingly, while $\mathrm{Al}_{3} \mathrm{Ni}$ is a line compound under equilibrium conditions, MA could result in its formation at compositions away from its stoichiometry. In the ball milled product, $\mathrm{NiAl}$ phase field manifests a large extension from $25-65$ at. $\% \mathrm{Ni}$ (equilibrium range is $45-58$ at. $\% \mathrm{Ni}$ ). Similarly disordered $\mathrm{Ni}_{3} \mathrm{Al}$ phase field has also been extended from $70-90$ at. $\% \mathrm{Ni}$, as against the narrow equilibrium range of $74-76$ at. $\% \mathrm{Ni}$ for ordered $\mathrm{Ni}_{3} \mathrm{Al}$. The results of MA of mixture of alloy powder and $\mathrm{Al}$ or $\mathrm{Ni}$ with compositions $\geqslant 25$ at. $\% \mathrm{Ni}$ are identical to those 


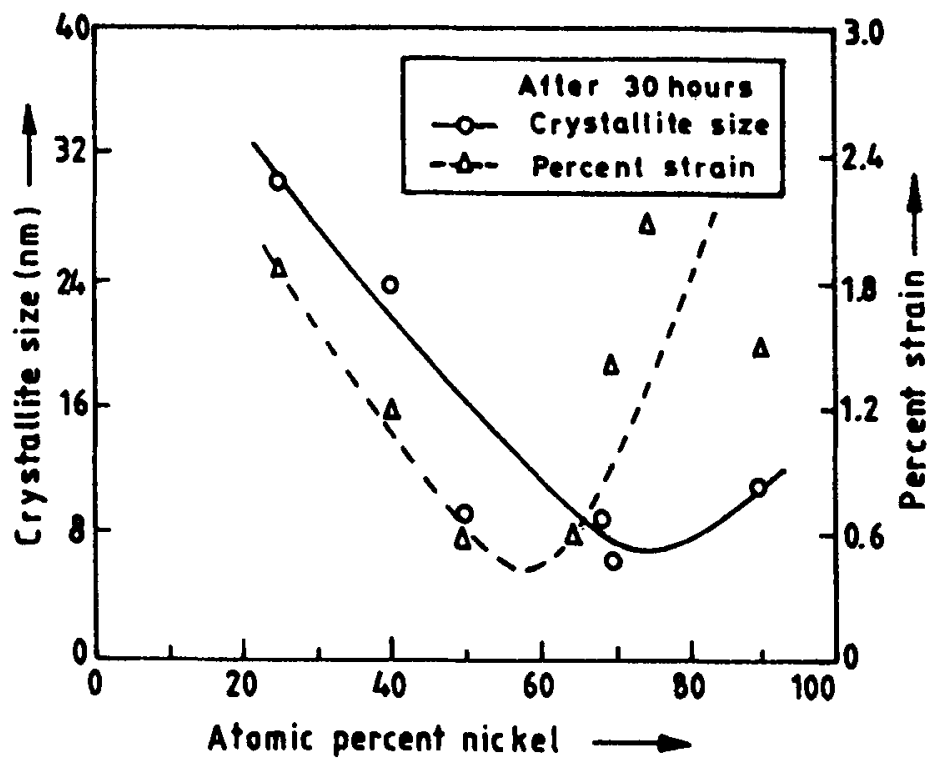

Figure 6. Variation of crystallite size and strain with composition in Ni-Al system after MA for $30 \mathrm{~h}$.

obtained for pure metal mixture as shown in figure 5 . For compositions $<25$ at. \% Ni, $\mathrm{NiAl}$ did not form by milling pure metal mixture, while in the case of mixture of alloy powder and $\mathrm{Al}$, the $\mathrm{NiAl}$ present in the alloy powder could not be destabilized by prolonged $\left(30 \mathrm{~h}\right.$ ) ball milling even in $\mathrm{Al}_{90} \mathrm{Ni}_{10}$ composition. However, it is interesting that, excepting the above fact, the other phases observed in the as milled condition were identical in both the cases.

The crystallite sizes and lattice strain after prolonged milling $(\sim 30 \mathrm{~h})$ of different alloy compositions are shown in figure 6 . It is interesting to note that crystallite size reaches a minimum $(\sim 6 \mathrm{~nm})$ at the compositions where a two-phase mixture of $\mathrm{NiAl}$ and $\mathrm{Ni}_{3} \mathrm{Al}$ coexists. The r.m.s strain appears to reach its minimum value near this range, possibly due to the ease of stress relaxation in smaller crystallite sizes. TEM study has confirmed that the crystallite size of $\mathrm{Al}_{3} \mathrm{Ni}$ is larger than that of $\mathrm{NiAl}$ and the observed sizes are in good agreement with the values estimated from XRD data.

\subsection{Synthesis of electron compounds in $\mathrm{Cu}-\mathrm{Zn}$ system by $\mathrm{MA}$}

3.2a Phase formation during MA: Nanocrystalline $\varepsilon, \gamma, \beta$ and $\alpha$ phases were synthesized by MA. Zn-rich phases were produced in the initial stages of MA process irrespective of the composition chosen. For example, in $\mathrm{Cu}-15$ at. $\% \mathrm{Zn}$, the $\varepsilon$ peaks were detected in the XRD pattern within $0.5 \mathrm{~h}$ of wet milling (figure 7). At this stage the crystallite size of $\mathrm{Cu}$ was quite coarse $(>200 \mathrm{~nm}$ ). Upon prolonged milling, more stable $\mathrm{Cu}$-rich phases formed, as is evident from figure 8 . The sequence of phase formation at all the compositions studied in this system is shown in table 1.

A sharp rise in the $\mathrm{Zn}$ content in the $\mathrm{Cu}$-rich $\alpha$-solid solution was observed after $\alpha$ reached a crystallite size of about $15 \mathrm{~nm}$ (after $\sim 4 \mathrm{~h}$ of milling), as shown in 


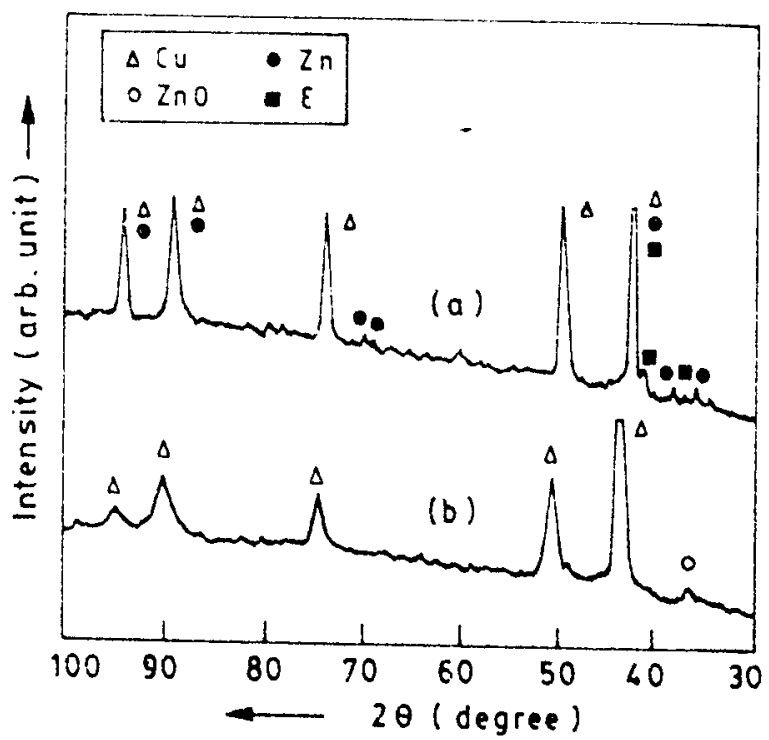

Figure 7. XRD patterns of $\mathrm{Cu}-15$ at. $\% \mathrm{Zn}$ after (a) $0.5 \mathrm{~h}$ and (b) $4 \mathrm{~h}$ of milling.

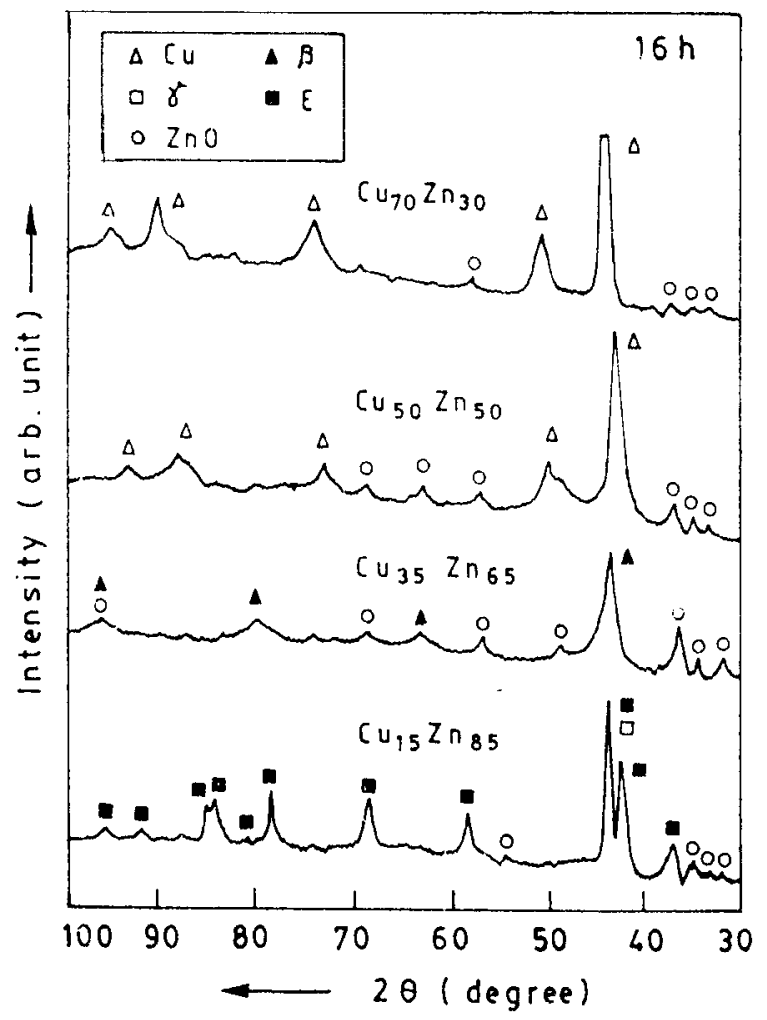

Figure 8. XRD patterns of different blends mechanically alloyed for $16 \mathrm{~h}$. 
Table 1. Transformation sequence during $M A$ of different $\mathrm{Cu}-\mathrm{Zn}$ blends.

\begin{tabular}{ll}
\hline Composition & Transformation sequence \\
\hline $\mathrm{Cu}_{85} \mathrm{Zn}_{15}$ & $\varepsilon \rightarrow \alpha+\mathrm{ZnO}$ \\
$\mathrm{Cu}_{70} \mathrm{Zn}_{30}$ & $\varepsilon+\gamma \rightarrow \beta \rightarrow \alpha+\mathrm{ZnO}$ \\
$\mathrm{Cu}_{60} \mathrm{Zn}_{40}$ & $\varepsilon+\gamma \rightarrow \beta+\alpha \rightarrow \alpha+\mathrm{ZnO}$ \\
$\mathrm{Cu}_{50} \mathrm{Zn}_{50}$ & $\varepsilon+\gamma \rightarrow \varepsilon+\gamma+\beta \rightarrow \beta+\mathrm{M} \rightarrow$ \\
$\mathrm{Cu}_{35} \mathrm{Zn}_{65}$ & $\beta+\alpha+\mathrm{ZnO} \rightarrow \alpha+\mathrm{ZnO}$ \\
$\mathrm{Cu}_{15} \mathrm{Zn}_{85}$ & $\varepsilon+\gamma \rightarrow \gamma \rightarrow \gamma+\beta+\mathrm{ZnO} \rightarrow \beta+\mathrm{ZnO}$ \\
\hline
\end{tabular}

$\mathbf{M}$, refers to martensite
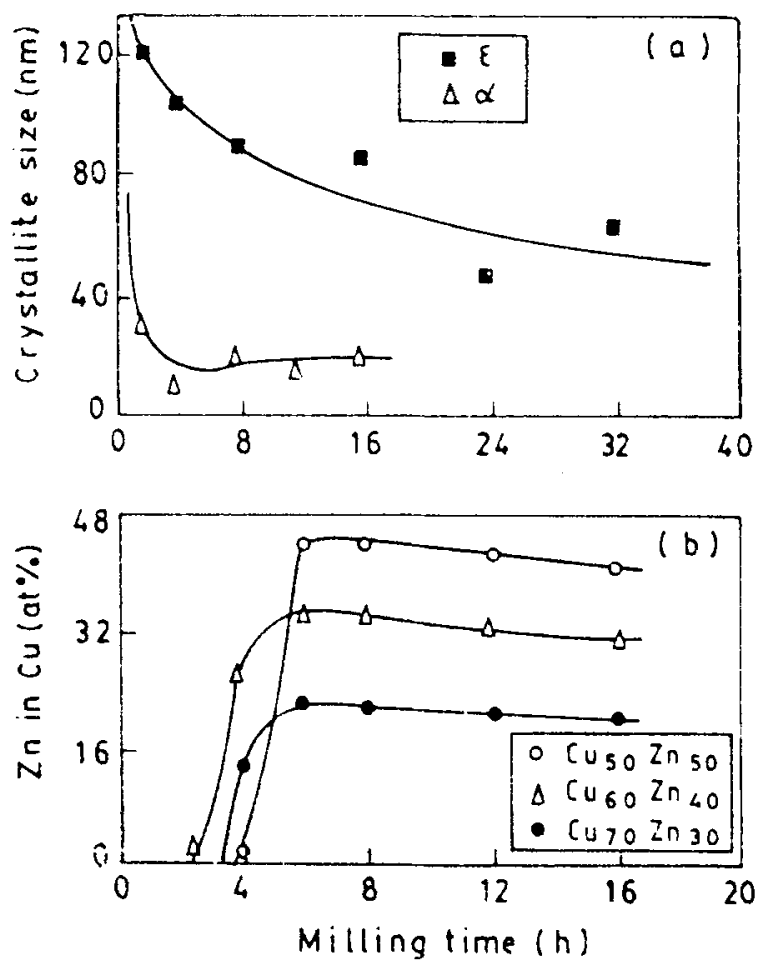

Figure 9. Change in (a) crystallite size and (b) $\mathrm{Zn}$ in $\mathrm{Cu}$-solid solution, as a function of milling time.

figures $9 \mathrm{a}$ and $\mathrm{b}$. The milling time and the crystallite size at which this fast enrichment of $\mathrm{Zn}$ in $\alpha$ occurred, was found to be quite insensitive to the composition of the elemental blend up to 50 at. \% of $\mathrm{Zn}$. In these alloys the maximum amount of $\mathrm{Zn}$ in $\alpha$ in course of MA (figure 9b) increased with the increase in $\mathrm{Zn}$ content of elemental blend, as expected. A marginal extension of the $\alpha$-phase field to $\sim 44$ at. $\% \mathrm{Zn}$ could be achieved in $\mathrm{Cu}_{50} \mathrm{Zn}_{50}$ blend. A gradual decrease of $\mathrm{Zn}$ in $\alpha$ was observed after milling beyond $8 \mathrm{~h}$, which was associated with the formation of $\mathrm{ZnO}$. 


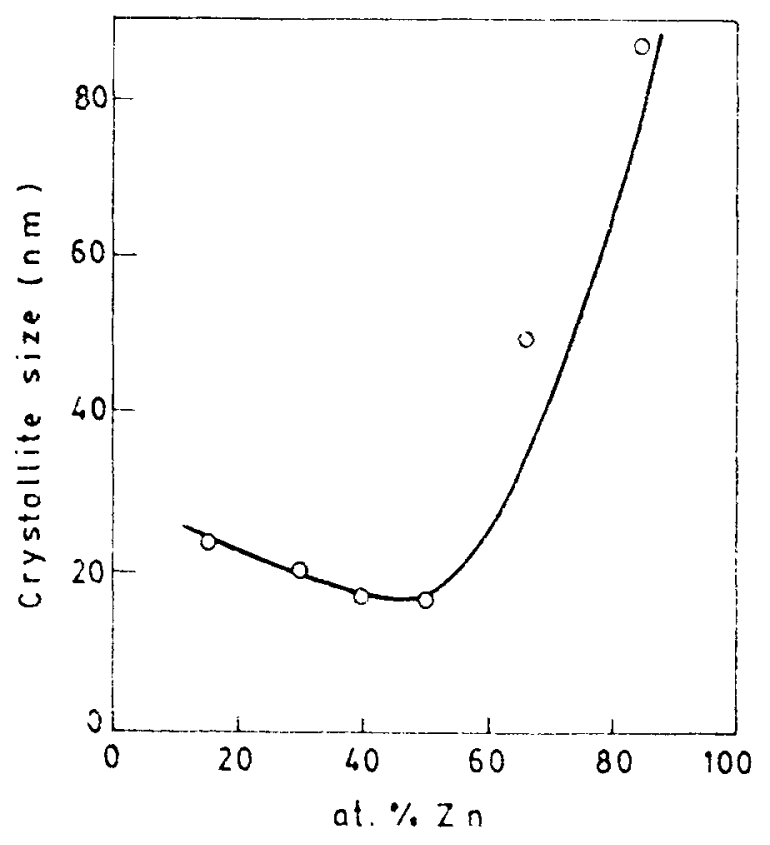

Figure 10. The crystallite size at different compositions after $16 \mathrm{~h}$ of milling.

At nominal compositions of 65 and 80 at. $\% \mathrm{Zn} . \beta$ and $(y+8)$ phases, respectively, were present after prolonged $(\sim 40 \mathrm{~h})$ milling, while the equilibrium phase diagram predicts single phase $\gamma$ and $\varepsilon$ formation at these compositions. In fact, as the milling of these two blends continued beyond $8 \mathrm{~h}$, the formation of $\mathrm{Cu}$-rich phases was found to be associated with the oxidation of $\mathrm{Zn}$-rich phases. A similar observation was reported in a recent work (Cardellini et al 1993) on elemental blends of Cu-80 and 85 at. \% Zn. However, for nominal compositions of $50 \mathrm{at} . \% \mathrm{Zn}$ or less, the Cu-rich phases were found to form by destabilization of $\mathrm{Zn}$-rich phases. The $\mathrm{ZnO}$ formation in these alloys became significant only at a much later stage.

The crystallite size of $Z n$-rich : phase decreased at a very slow rate with increase in the milling time when compared to $x$ phase (figure $9 \mathrm{a}$ ). For instance, after $40 \mathrm{~h}$ of milling, the crystallite size of $\varepsilon$ phase was about $40 \mathrm{~nm}$. while the $\alpha$ phase reached a crystallite size of $\sim 15 \mathrm{~nm}$ within $4 \mathrm{~h}$ of milling. This difference could be attributed to the difference in the melting points of the $x$ and $s$ phases (Koch 1993), since the tendency for cold welding in the case of low melting phases is expected to be more. Among the different compositions studied, the crystallite size was found to reach a minimum $(\sim 18 \mathrm{~nm})$ in the $\alpha$-phase at the phase boundary of $\alpha$ and $\beta$ (figure 10). A similar result was also observed in the $\mathrm{Ni}-\mathrm{Al}$ system at the phase boundary of $\mathrm{NiAl}$ and $\mathrm{Ni}_{3} \mathrm{Al}$. It is also interesting to note that no such minimum is observed at the $\gamma$ and $\varepsilon$ phase boundary. These results probably suggest that the nanocrystalline mixtures of only the high melting phases mutually hinder the coalescence of crystallites.

Nanocrystalline nature of the alloys obtained by MA was confirmed by TEM studies. The crystallite size of $\alpha$ phase observed by TEM (figure 11 ) in $\mathrm{Cu}_{50} \mathrm{Zn}_{50}$ blend seems to be in good agreement with the average size of $\sim 18 \mathrm{~nm}$ as measured by XRD. The selected area electron diffraction pattern (inset of figure 11) corresponds to the $\alpha$ phase, and shows no evidence of amorphization. 
Figure 11. TEM bright field image of $\alpha$ in $\mathrm{Cu}_{50} \mathrm{Zn}_{50}$ milled for $16 \mathrm{~h}$. Inset is the selected area diffraction pattern of the phase.

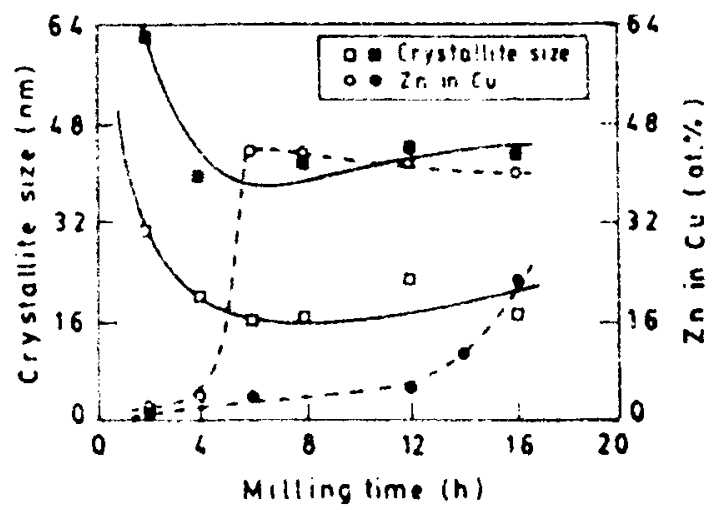

Figure 12. Time modulation of crystallite size (- - ) ) and $\mathrm{Zn}$ in $\mathrm{Cu}$-solid solution (---) during dry (filled symbols) and wet (open symbols) milling of $\mathrm{Cu}_{50} \mathrm{Zn}_{50}$ blend.

3.2b Effect of milling parameters: A significant role of milling atmosphere on phase formation was evident from the dry and wet milling studies. While rapid alloying was observed on wet milling of $\mathrm{Cu}_{70} \mathrm{Zn}_{30}$, dry milling resulted in only oxide formation and no significant alloying could be detected even after $16 \mathrm{~h}$ of milling. In $\mathrm{Cu}_{50} \mathrm{Zn}_{50}$, formation of alloy phases was observed both in dry and wet milling conditions. However, during wet milling, a much more rapid crystallite size reduction and alloying (figure 12) were achieved as compared to dry milling of this composition. Sluggish rate of alloying in the dry milling operation is also associated with the early formation of 


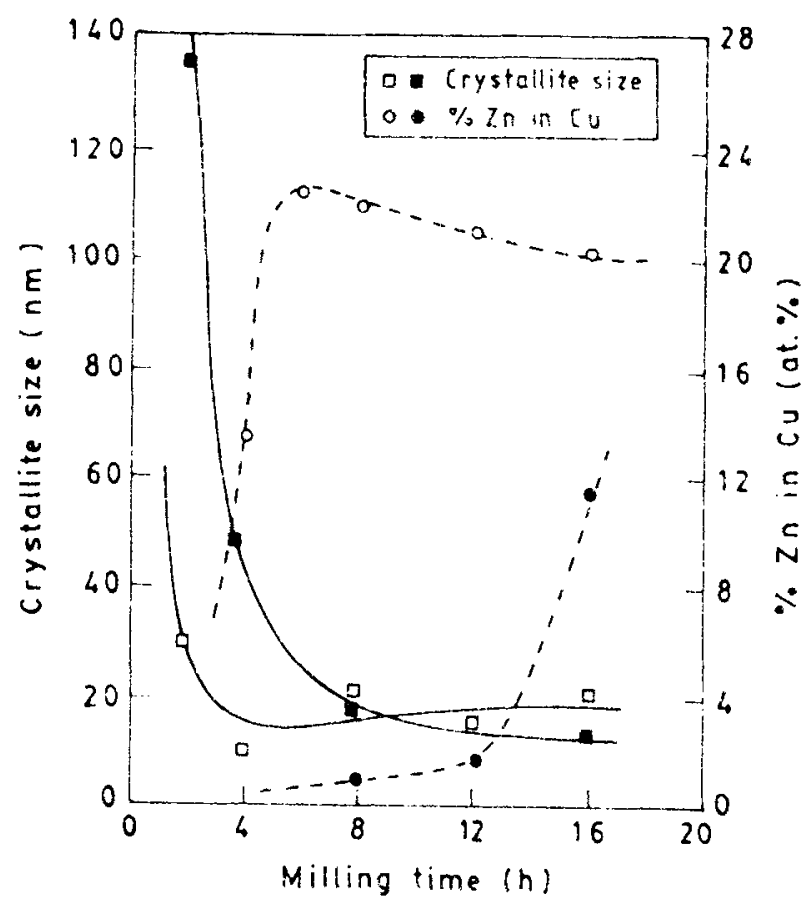

Figure 13. Crystalle relinerent

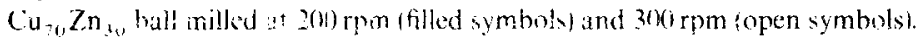

$\mathrm{ZnO}$, as evidenced by the $\mathrm{XR} \mathrm{D}$ results. Possinly the oxide layer acts as a barrier and retards or prevents the alloying process.

A comparative study of wet milling of $\mathrm{Cu}_{30} \mathrm{Zn}_{30}$ blend in steel grinding media. performed at different milling speeds of 200 and $300 \mathrm{rpm}$ showed a faster drop in crystallite size in the initial stage of milling in the later case (figure 13). However, the final crystallite size of $x$ after $16 \mathrm{~h}$ of milling was marginally lower at $200 \mathrm{rpm}$. This indicates that there is an optimum energy for grinding at which the fracture and cold welding processes strike a balance to vield the finest crystalite size in a system.

The contribution of higher energy imparted with WC medium is similar to that of higher milling speed, excepting the latger quantity of powder being employed in the former case for the same B P ratio. Wet milling of $C \mathrm{U}_{-0} \mathrm{Zn}_{3 n}$ blend at B/P wt. ratio of 10:1 and milling speed of $300 \mathrm{rpm}$ in WC media showed the formation of metastable strain induced martensite within 1 h of milling. Similar ohservation has heen reported earlier (McDermott and Koch 1986) in the equiatomic blend. However, no such transformation could be detected in steel media. The higher specific gravity of WC as compared to steel imparts higher energy to the powder particles and probably introduces larger strain in the system sufficient to trigger the martensite formation. This martensite disappears during further milling possibly due to its compositional change. A much pronounced particle coarsening was observed in WC media after an initial drop in crystallite size (figure 14). This indicates more cold welding at higher milling energy. In $\mathrm{Cu}_{70} \mathrm{Zn}_{30}$ blend a marginal increase in the maximum $\mathrm{Zn}$ content in $x$ to $\sim 23.3$ at $\%$ (from 22 at. $\%$ in steel vial) was also achieved in WC medium (figure 8) apparently due to higher energy transfer in this medium. 


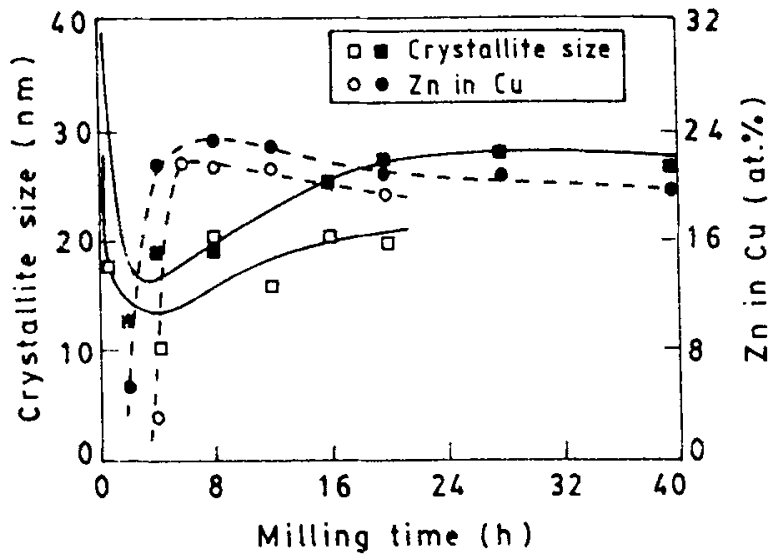

Figure 14. Change in crystallite size (-_-) and $\mathrm{Zn}$ content in $\mathrm{Cu}(---)$ in $\mathrm{Cu}_{70} \mathrm{Zn}_{30}$ blend milled in steel (open symbols) and WC (filled symbols) medium at different milling time.

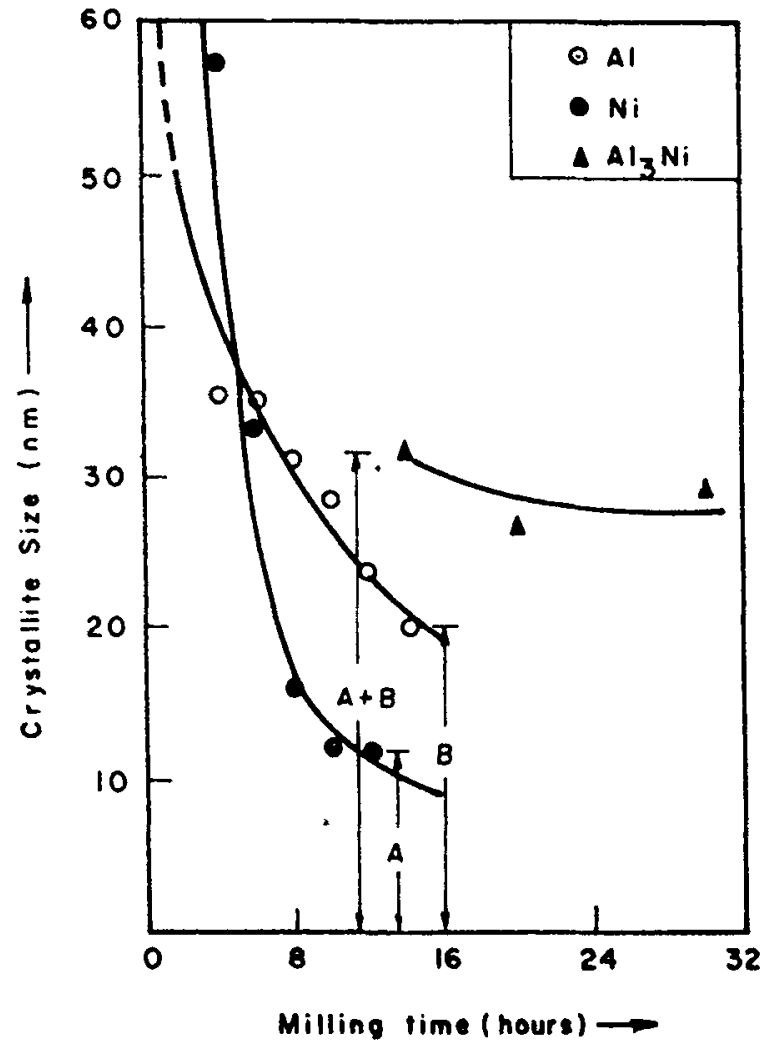

Figure 15. Variation of crystallite size of constituent metals with milling time during the formation of $\mathrm{Al}_{3} \mathrm{Ni}$ in $\mathrm{Al}_{79} \mathrm{Ni}_{21}$ blend.

\subsection{Mixing phenomenon}

3.3a Ni-Al system: Observation of XRD patterns of different compositions in this system has shown that ordered $\mathrm{Al}_{3} \mathrm{Ni}$ and $\mathrm{NiAl}$ form all of a sudden, while disordered 


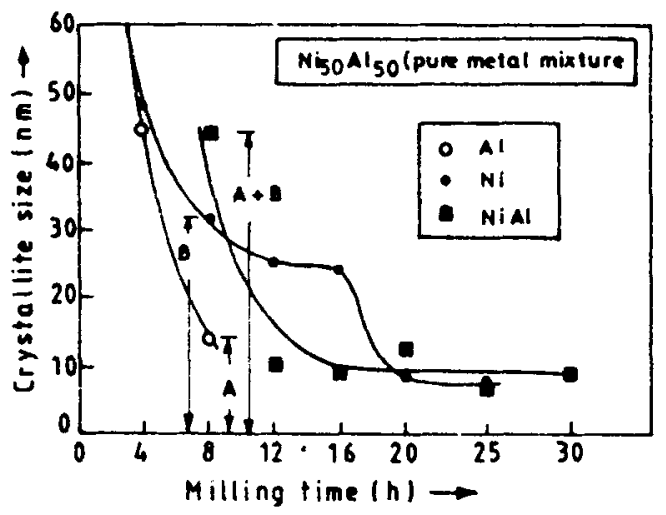

Figure 16. Variation of crystallite size of constituent metals with milling time during the formation of $\mathrm{NiAl}$ in $\mathrm{Al}_{50} \mathrm{Ni}_{50}$ blend.

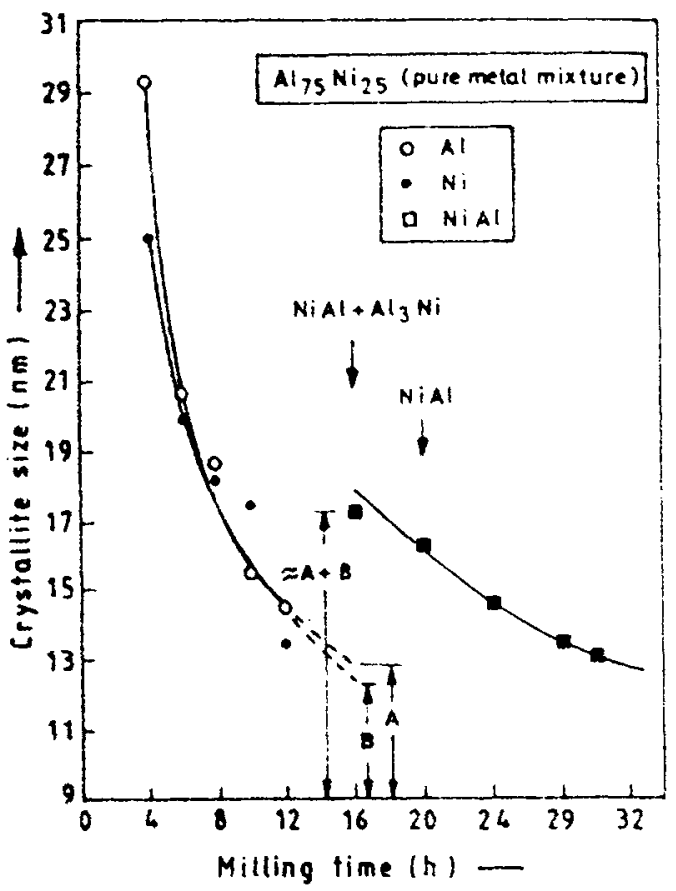

Figure 17. Variation of crystallite size of constituent metals with milling time during the formation of $\mathrm{NiAl}$ in $\mathrm{Al}_{75} \mathrm{Ni}_{25}$ blend.

$\mathrm{Ni}_{3} \mathrm{Al}$ forms by continuous shifts in Ni peaks. Study of the crystallite sizes has evidenced the $\mathrm{NiAl}$ or $\mathrm{Al}_{3} \mathrm{Ni}$ formation is triggered only when $\mathrm{Al}$ and $\mathrm{Ni}$ reach critical nanocrystalline sizes. In both the cases it was observed that the crystallite sizes of $\mathrm{Al}_{3} \mathrm{Ni}$ and $\mathrm{NiAl}$ at the time of their formation, were equal to the sum of the crystallite sizes of their constituents ( $\mathrm{Al}$ and $\mathrm{Ni}$ ) as shown in figures 15 and 16, respectively. The critical crystallite sizes of $\mathrm{Ni}$ and $\mathrm{Al}$ required for the onset of $\mathrm{NiAl}$ formation in $\mathrm{Al}_{50} \mathrm{Ni}_{50}$ composition are found to be larger than that in $\mathrm{Al}_{75} \mathrm{Ni}_{25}$ (cf. figures 16 and 17). 
3.3b $\quad \mathrm{Cu}-\mathrm{Zn}$ system: It is apparent from the present study on $\mathrm{Cu}-\mathrm{Zn}$ system that irrespective of the blend composition, the $\mathrm{Zn}$-rich $\varepsilon$ and $\gamma$ phases are first to form in the early stages of MA. Rapid diffusion of $\mathrm{Zn}$ into $\mathrm{Cu}$ and formation of $\alpha$ phase was observed only after $\mathrm{Cu}$ crystallites reached almost $15 \mathrm{~nm}$ size. Further, it appears that for compositions $<50$ at. $\% \mathrm{Zn}$, the $\mathrm{Cu}$-rich phases have formed by direct destabilization of $\mathrm{Zn}$-rich phases due to diffusion of $\mathrm{Cu}$, while in blends containing $>50$ at. $\%$ $\mathrm{Zn}$, the $\mathrm{Cu}$ rich phases seemed to form due to the loss of $\mathrm{Zn}$ from $\mathrm{Zn}$-rich phases by oxidation. The pattern of XRD peak shift and crystallite size measurements reveal that the phases in $\mathrm{Cu}-\mathrm{Zn}$ system form by diffusion of $\mathrm{Cu}$ and $\mathrm{Zn}$ in each other in course of milling in a manner similar to the mechanism of formation of disordered $\mathrm{Ni}_{3} \mathrm{Al}$. The only difference in these two cases is that in $\mathrm{Cu}-\mathrm{Zn}$ system, diffusion of both $\mathrm{Cu}$ and $\mathrm{Zn}$ in each other was responsible for the formation of different phases, while the formation of disordered $\mathrm{Ni}_{3} \mathrm{Al}$ was caused predominantly by the diffusion of $\mathrm{Al}$ into $\mathrm{Ni}$.

\section{Discussion}

\subsection{Phase formation during $M A$}

The stability of $\mathrm{Al}_{3} \mathrm{Ni}$ in blend compositions of $\mathrm{Al}_{82} \mathrm{Ni}_{18}$ and $\mathrm{Al}_{79} \mathrm{Ni}_{21}$, which deviate away from its stoichiometric composition $\left(\mathrm{Al}_{75} \mathrm{Ni}_{25}\right)$, suggests that there could be some loss of $\mathrm{Al}$ due to oxidation in course of $\mathrm{MA}$, thus shifting the alloy composition towards the stoichiometry of $\mathrm{Al}_{3} \mathrm{Ni}$. For similar reason $\mathrm{Al}_{3} \mathrm{Ni}$ may become unstable during $\mathrm{MA}$ of $\mathrm{Al}_{75} \mathrm{Ni}_{25}$ blend. The chemical analysis of the mechanically alloyed samples reported in table 2 has confirmed this conjecture. A similar effect of oxidation has been reported earlier for $\mathrm{Al}-\mathrm{Fe}$ system (Mukhopadhyay et al 1994), where $\mathrm{Al}_{5} \mathrm{Fe}_{2}$ ( 28 at. \% Fe) forms by $\mathrm{MA}$ of an elemental blend of $\mathrm{Al}_{75} \mathrm{Fe}_{25}$ instead of the expected $\mathrm{Al}_{3} \mathrm{Fe}$. However, the stability of ordered $\mathrm{Al}_{3} \mathrm{Ni}$ in nanocrystalline powders containing 22 to 24 at. \% $\mathrm{Ni}$ is quite interesting in view of the fact that $\mathrm{Al}_{3} \mathrm{Ni}$ is a line compound under equilibrium condition. This suggests that ordered $\mathrm{Al}_{3} \mathrm{Ni}$ can accommodate some structural defects in $\mathrm{Ni}$-sublatlice induced by milling. However, milled $\mathrm{Al}_{3} \mathrm{Ni}$ seems to be less tolerant to deficiencies in Al-sublattice, since it becomes unstable in ball milled alloys containing $>25$ at. $\% \mathrm{Ni}$.

In contrast to $\mathrm{Al}_{3} \mathrm{Ni}$, the stability of ordered $\mathrm{NiAl}$ seems to be quite insensitive to both the compositional variations in binary system and the structural defects induced by MA. Similar results have also been reported by other investigators (Itsukaichi et al 1993; Cardellini et al 1994). Under ball milled condition nanocrystalline NiAl phase field could be extended more towards Al-rich side (up to 25 at.\% Ni compared to equilibrium 45 at. $\% \mathrm{Ni}$ ) than towards $\mathrm{Ni}$-rich side (i.e. up to 65 at. $\% \mathrm{Ni}$ compared to 58

Table 2. Results of chemical analysis of milled powders of $\mathrm{Ni}-\mathrm{Al}$ system.

\begin{tabular}{lcc}
$\begin{array}{l}\text { Initial composition of } \\
\text { elemental blend }\end{array}$ & $\begin{array}{c}\text { Composition of } \\
\text { powder milled for } \\
\text { (at \% } \% \mathrm{Ni})\end{array}$ & $\begin{array}{c}\text { Phases observed in } \\
\text { XRD of milled } \\
\text { product }\end{array}$ \\
\hdashline 18 & 22 & $\mathrm{Al}+\mathrm{Al}_{3} \mathrm{Ni}$ \\
21 & 24 & $\mathrm{Al}_{3} \mathrm{Ni}$ \\
25 & 27 & $\mathrm{NiAl}$ \\
\hline
\end{tabular}


at. \% $\mathrm{Ni}$ in equilibrium diagram). This is in agreement with earlier studies on conventional NiAl structure, which show its more tolerance to vacancies in $\mathrm{Ni}$-sublattice than Al-sublattice (Noebe et al 1993).

It may also be noted that the critical temperature of ordering $T_{\mathrm{c}}$ for $\mathrm{NiAl}$ varies in proximity of its melting point over a wide range of composition, and it declines only in the vicinity of $\mathrm{NiAl}-\mathrm{Ni}_{3} \mathrm{Al}$ phase boundary (Noebe et al 1993). Unlike the case of $\mathrm{Al}_{3} \mathrm{Ni}$ or $\mathrm{NiAl}$, the order parameter of $\mathrm{Ni}_{3} \mathrm{Al}$ seems to be very sensitive to the structural defects induced by high energy ball milling, and $\mathrm{Ni}_{3} \mathrm{Al}$ was disordered even at its stoichiometric composition. It is interesting to note that even after large number of investigations in this area (Atzmon 1988; Cardellini et al 1993; Itsukaichi et al 1993), there exists no report of direct synthesis of ordered $\mathrm{Ni}_{3} \mathrm{Al}$ by $\mathrm{MA}$. The low ordering energy $(5 \mathrm{~kJ} / \mathrm{mol})$, low ordering temperature $(638 \mathrm{~K})$ (Koch and Cho 1992) and the close packed nature of the crystal structure seem to be the reasons for the easy destabilization of the order in $\mathrm{Ni}_{3} \mathrm{Al}$ during milling. The extension of $\mathrm{Ni}_{3} \mathrm{Al}$ in its disordered condition during MA (70-90 at. \% Ni) in comparison to the equilibrium phase field of ordered $\mathrm{Ni}_{3} \mathrm{Al}(74-76$ at. $\% \mathrm{Ni})$ also could be related to the above reasons. Finally, the fact that the phases and phase fields obtained in $\mathrm{Ni}-\mathrm{Al}$ system by MA are more or less identical for both types of starting blends, namely, pure metal mixtures and mixtures of alloy powder with $\mathrm{Al}$ or $\mathrm{Ni}$, indicates that phases during $\mathrm{MA}$ arise out of thermodynamic reasons.

\subsection{Mechanism of alloying}

Present study on $\mathrm{Ni}-\mathrm{Al}$ system shows that ordered $\mathrm{NiAl}$ and $\mathrm{Al}_{3} \mathrm{Ni}$ form suddenly after individual constituents reach some critical nanocrystalline size. The sudden exothermic reaction in the vial to yield $\mathrm{NiAl}$ in $\mathrm{Ni}_{50} \mathrm{Al}_{50}$ mixture reported by Atzmon (1988) is a characteristic of reactive mixing. However. in a typical reactive mixing the zone of reaction usually spreads in an unrestrained fashion. In the present case, however, it is found that crystallite size of the ordered products is the sum of the individual crystallite sizes of $\mathrm{Ni}$ and $\mathrm{Al}$, irrespective of the composition chosen. Hence, to distinguish this process from gradual diffusive or conventional reactive mixing, $\mathrm{NiAl}$ and $\mathrm{Al}_{3} \mathrm{Ni}$ formation mechanism may be termed as 'discontinuous additive intermixing', as indicated in table 3 . It is also conceivable that large scale and rapid intermixing of two constituents to yield an ordered product may involve a moving boundary process, once the product phase is nucleated.

In case of formation of an ordered reaction product like $\mathrm{NiAl}$ or $\mathrm{Al}_{3} \mathrm{Ni}$, the contribution of entropy change to the driving force may not be significant. Therefore, in these cases the larger the $\Delta H_{f}$, the higher would be the driving force for the reaction. It

Table 3. Characteristic features of MA of $\mathrm{Cu}-\mathrm{Zn}$ and $\mathrm{Ni}-\mathrm{Al}$ systems.

\begin{tabular}{lcccc}
\hline System & Phase & $\Delta H_{\mathrm{f}}(\mathrm{kJ} / \mathrm{mol})$ & Product & Mode of mixing \\
\hline $\mathrm{Cu}-\mathrm{Zn}$ & $\varepsilon$ & 7 & disordered & continuous diffusive \\
& $\alpha$ & 8 & disordered & $\begin{array}{c}\text { continuous diffusive } \\
\mathrm{Ni}-\mathrm{Al}\end{array}$ \\
& $\mathrm{Al}_{3} \mathrm{Ni}$ & 150 & ordered & discontinuous additive \\
& $\mathrm{NiAl}^{\mathrm{NiAl}}$ & 118 & ordered & discontinuous additive \\
& $\mathrm{Ni}_{3} \mathrm{Al}$ & 153 & disordered & continuous diffisive \\
\hline
\end{tabular}


is expected that the critical crystallite size at which such discontinuous mixing triggers, should diminish with the increase in driving force. This explains why critical crystallite sizes of $\mathrm{Al}$ and $\mathrm{Ni}$ for the formation of $\mathrm{NiAl}$ are higher in $\mathrm{Al}_{50} \mathrm{Ni}_{50}$, than in $\mathrm{Al}_{75} \mathrm{Ni}_{25}$. It is known that the $\Delta H_{\mathrm{f}}$ of $\mathrm{NiAl}$ is maximum at its stoichiometric composition and decreases on either side (Noebe et al 1993).

In $\mathrm{Ni}_{3} \mathrm{Al}$, the $\Delta H_{\mathrm{f}}$ is large $(150 \mathrm{~kJ} / \mathrm{mol})$ and comparable to that for $\mathrm{NiAl}$ or $\mathrm{Al}_{3} \mathrm{Ni}$ (Kubaschewski et al 1967a) (cf. table 3). However, $\mathrm{Ni}_{3} \mathrm{Al}$ is unable to retain its ordered structure in ball milled condition possibly due to its low ordering energy $(5 \mathrm{~kJ} / \mathrm{mol})$ (Aoki et al 1994). Since both $\mathrm{Ni}$ and disordered $\mathrm{Ni}_{3} \mathrm{Al}$ are fcc, under ball milling condition, $\mathrm{Ni}_{3} \mathrm{Al}$ loses its order and distinction with the solid solution of $\mathrm{Al}$ in $\mathrm{Ni}$. This can explain why alloying in $\mathrm{Ni}-\mathrm{Al}$ blends containing $\geqslant 70$ at. $\% \mathrm{Ni}$ takes place by gradual enrichment of $\mathrm{Ni}$ with $\mathrm{Al}$ in a manner suggested by Zbiral et al (1992). It may be mentioned that the equilibrium solubility of $\mathrm{Ni}$ in $\mathrm{Al}$ is smaller when compared to $\mathrm{Al}$ in $\mathrm{Ni}$. Hence, $\mathrm{Al}$ is expected to be the major diffusing species in a couple of $\mathrm{Ni}-\mathrm{Al}$. The absence of XRD peak shift for $\mathrm{Al}$ and the large peak shifts of Ni observed in course of MA support this mechanism. Table 3 summarizes the alloying characteristics of Ni-aluminides. It is apparent that disordered phase forms by continuous diffusive mixing during MA, even if $\Delta H_{\mathrm{f}}$ is large.

In $\mathrm{Cu}-\mathrm{Zn}$ system, the alloying was again observed to be by continuous diffusive mixing. This is expected, as $\Delta H_{\mathrm{f}}$ of the phases in this system is quite low $(8 \mathrm{~kJ} / \mathrm{mol})$ (Kubaschewski et al 1967b). However, it is interesting to note that alloying is initiated by the diffusion of $\mathrm{Cu}$ into $\mathrm{Zn}$, while the reverse is expected from the solubility point of view. This is not difficult to understand, if one looks into the diffusivities of $\mathrm{Cu}$ and $\mathrm{Zn}$ in each other. It is clear from the simulation studies (Schwarz and Koch 1986) and the results of ball milling of Fe-C martensite (Davis et al 1988), that the local rise in temperature at the point of impact on a particle in a mill is not appreciable. Assuming a temperature of about $200^{\circ} \mathrm{C}$, the diffusivities of $\mathrm{Cu}$ in $\mathrm{Zn}$ and $\mathrm{Zn}$ in $\mathrm{Cu}$ extrapolated from high temperature data are $3.0 \times 10^{-18}$ and $8.2 \times 10^{-27} \mathrm{~m}^{2} / \mathrm{s}$, respectively (Weast 1979). Since the diffusivity of $\mathrm{Cu}$ in $\mathrm{Zn}$ is about eight orders of magnitude higher than $\mathrm{Zn}$ in $\mathrm{Cu}$, alloying is expected to initiate by the diffusion of $\mathrm{Cu}$ in $\mathrm{Zn}$ and the formation of $\mathrm{Zn}$-rich phases such as $\varepsilon$ and $\gamma$. Diffusion of $\mathrm{Zn}$ into $\mathrm{Cu}$, and formation of $\alpha$ phase gains momentum only after the crystallite size of $\mathrm{Cu}$ is brought down to a few nanometers, so that the diffusion distances become small enough. Thus, it is observed from table 3 , that the mode of mixing is continuous diffusive, if either the $\Delta H_{\mathrm{f}}$ or the order energy is very low for any given compound. However, the major diffusing species in either case is decided by mutual solubilities and individual intrinsic diffusivities of the constituents.

\section{Conclusions}

(I) Nanocrystalline ordered $\mathrm{Al}_{3} \mathrm{Ni}, \mathrm{NiAl}$ and disordered $\mathrm{Ni}_{3} \mathrm{Al}$ have been directly synthesized by MA. The phase fields of the above phases have been extended from $22-25,25-65$ and $70-90$ at. \% Ni, respectively. For a given composition, the metastable equilibrium achieved by ball milling seem to be insensitive to the structure of the starting blends.

(II) Stability of ordered $\mathrm{Al}_{3} \mathrm{Ni}$ and, in particular, $\mathrm{NiAl}$ seem to be insensitive to the structural defects induced by milling, while ordered $\mathrm{Ni}_{3} \mathrm{Al}$ was not stable under present milling conditions. 
(III) Nanocrystalline solid solution ( $\alpha$ ) and electron compounds such as $\beta, \gamma$ and $\varepsilon$ could be generated in $\mathrm{Cu}-\mathrm{Zn}$ system by MA.

(IV) The crystallite sizes are found to be dependent on the melting point and reached a minimum in the two-phase field of high melting, brittle compounds.

(V) The direct synthesis of ordered $\mathrm{Al}_{3} \mathrm{Ni}$ or $\mathrm{NiAl}$ involving a large $\Delta H_{\mathrm{f}}$ seems to take place through a discontinuous additive mixing mechanism. In contrast, when the ordering energy or heat of formation is low, the alloying apparently occurs through a continuous diffusive mechanism.

\section{Acknowledgements}

The work was sponsored by the Department of Science and Technology, Govt. of India (Grant No. III. 4(23)/92-ET). BSM is thankful for the financial assistance provided by ISIRD, IIT, Kharagpur. The technical help of Mr J Joardar, K H S Singh and P De is thankfully acknowledged.

\section{References}

Aoki K, Wang X M, Mcmezawa A and Masumoto T 1994 Mater. Sci. Engg. A179/180 390

Atzmon M 1988 Phys. Rev. Lett. 64487

Benjamin J S 1970 Metall. Trans. 12943

Benn R C, Mirchandani P K and Watwe A S 1988 Modern developments in powder metallurgy (Princeton: MPIF) p. 479

Calka A and Radlinski A P 1990 J. Less Common Metals 161 L23

Cardellini F, Contini V, Mazzone G and Vittori M 1993 Scr. Metall. Mater. 281035

Cardellini F, Mazzone G, Montone A and Antisare M V 1994 Acta Metall. Mater. 422445

Das A and Pabi S K 1996 Metals. Materials and Processes (in press)

Davis R M, McDermott B T and Koch C C 1988 Metall. Trans. A19 2867

Gleiter H 1992 Nanostructured Mater. 11

Guinier A $1963 X$-ray diffraction (San Francisco: Freeman) p. 124

Itsukaichi T, Umemoto M and Moreno J G C 1993 Scr. Metall. Mater. 29583

Ivanov E, Grigorieva T, Gdubkova G, Boldyrev V, Fasman A B, Mikhailenko S D and Kalinina O T 1990 Mater. Lett. 751

Koch C C 1991 Processing of metals and alloys (ed) R W Cahn (New York: VCH Publications) p. 193

Koch C C 1993 Nanostructured Mater. 2109

Koch C C and Cho Y S 1992 Nanostructured Mater. 1207

Kubaschewski O, Evans E L and Alcock C B 1967a Metallurgical thermochemistry (Oxford: Pergamon Press) p. 342

Kubaschewski O, Evans E L and Alcock C B $1967 \mathrm{~b}$ Metallurgical thermochemistry (Oxford: Pergamon Press) p. 438

McDermott B T and Koch C C 1986 Scr. Metall. 20669

Miracle D B 1993 Acta Metall. Mater. 41649

Mukhopadhyay D K, Suryanarayana C and Froes F H 1994 Scr. Metall. Mater, 31333

Munir Z A 1992 Metall. Trans. A23 7

Murty B S 1992 Study of amorphous phase formation by mechanical alloying in Tibased systems, Ph. D Thesis, Indian Institute of Science, Bangalore

Murty B S 1993 Bull. Mater. Sci. 161

Murty B S, Singh H S and Pabi S K 1996 Bull. Mater. Sci. 19565

Neiman G W, Weertman J R and Siegel R W 1991 Clusters and cluster-assembled materials (eds) R S Averback, J Bernholc and D L Nelson (Pittsburgh: MRS) p. 493

Noebe R D, Bowman R R and Nathal M V 1993 Int. Mater. Rev. 38193

Pabi S K and Murty B S 1996 Mater. Sci. Engg. A214 146 
Pabi S K, Joardar J and Murty B S 1996 J. Mater. Sci. 313207

Radlinski A P and Calka A 1991 Mater. Sci. Engg. A134 1376

Schwarz R B and Koch C C 1986 Appl. Phys. Lett. 49146

Shingu P H 1992 Mechanical Alloying, Mater. Sci. Forum 88-90

Weast R C 1979 CRC Handbook of Chemistry and Physics (Ohio: CRC Press Inc.) 58 p. F-62

Zbiral J, Jangg G and Korb G 1992 Mater. Sci. Forum 88-90 19 